\title{
Causes, consequences and control of student protests
}

\author{
Adams Ogirima \\ Onivehu
}

\section{Contact}

University of Ilorin Faculty of Education P.M.B. 1515, Ilorin Kwara State, Nigeria adamsonivehu@gmail.com

$\triangle$ Correspondence: adamsonivehu@gmail.com

Copyright (C) 2021 by the author and publisher, TBU in Zlín.

This work is licensed under the Creative Commons Attribution International License (CC BY).

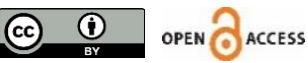

\begin{abstract}
This study investigated the causes, consequences and control of student protests, especially the EndSARS (Special AntiRobbery Squad) protest. A descriptive survey was adopted for the study. A total of 600 undergraduates, selected by multi-stage sampling, participated in the study. Three research questions were raised and a questionnaire titled Causes, Consequences and Control of Youth Protest Questionnaire (CCCYPQ) was used to collect data. The findings showed that the protest was caused by extra-judicial killings, assaults, harassment, extortion, bad governance, and youth unemployment. In addition, the findings indicated that the consequences of the protest include destruction of lives and property, hacking of the websites of public ministries, departments, agencies and corporate organizations, destruction of public infrastructural facilities, and disruption of academic activities in schools. The various control measures include disbandment of SARS, compensation for victims of police brutality, and provision of skills acquisition programmes and employment opportunities for youths. There were no significant gender differences in the perceived causes, consequences and control of the protest. Based on the findings, it was recommended that dialogue and collaborative decisionmaking should be employed in controlling student protest.
\end{abstract}

Keywords: causes, consequences, control, protest, student, EndSARS, gender

\section{Příčiny, následky a kontrola studentských protestů}

Abstrakt: Tato studie vyšetřuje příčiny, následky a kontrolu
studentských protestů, obzvláště pak protest EndSARS (Speciální
oddíl proti loupežím). Pro studii byl zvolen popisný výzkum.
Zúčastnilo se jí celkem 600 vysokoškolských studentư zvolených
vícefázovým vzorkováním. Položeny byly tři výzkumné otázky
a ke shromáždění dat byl použitý dotazník Príčiny, následky
a kontrola protestů mládeže (CCCYPQ). Zjištění ukázala,
že protesty byly zapríčiněny mimosoudním zabitím, napadeními,
obtěžováním, vydíráním, špatným vládnutím a nezaměstnaností
mládeže. Dále zjištění naznačila, že následky protestů zahrnují
ničení života a majetku, hacking internetových stránek
ministerstev a vládních úřadů, agentur a firem, ničení vybavení
veřejné infrastruktury a narušování akademických aktivit
ve školách. Ke kontrolním opatřením patří rozpuštění SARS,
kompenzace pro oběti policejní brutality a programy pro získání
dovedností a pracovních příležitosti pro mládež. Ve vnímaných 
prrícinách, následcích a kontrole protestů se nevyskytovaly výrazné genderové rozdíly. Na základě zjištění bylo doporučeno, aby se při kontrole studentských protestů využíval dialog a společné rozhodování.

Klíčová slova: příčiny, následky, kontrola, protest, student, EndSARS, gender

\section{Introduction}

Protest is a global phenomenon. Therefore, the past decade is saturated with instances of protests across the world, such as Occupy Wall Street, the Spanish Indignados, the first Arab Spring uprising of 2010 in Tunisia and Egypt, and the second Arab Spring in Morocco, Jordan, Sudan, Algeria, Egypt, Lebanon, Iraq and Syria in the period of 2018-2020. The Black Lives Matter movement, Gorge Floyd and anti-lockdown protests were also carried out in various nations, such as the United States of America, Canada, Australia, New Zealand and the United Kingdom, Italy, Spain, Germany, the Czech Republic and other European nations. Similarly, the South American nations (Brazil, Ecuador, Chile, Argentina, Bolivia, Colombia, Peru and Venezuela) also experienced widespread protests due to long periods of frustrations, dissatisfaction with the social policies of governments and mismanagement of the COVID-19 pandemic. In Asia, common protests included the labour protests in China, the AntiExtradition Law Amendment Bill movement in Hong Kong (2019-2020), the Candlelight Struggle or Candlelight Revolution of South Korea (2016-2017) and a host of others. In the African setting, common protests included protests related to the COVID-19 pandemic, the Fees Must Fall protest (2015-2016) and xenophobic protests in South Africa, the Malian spring protests of 2020, and the anti-third-term presidential bid protests in Ivory Coast in the run-up to the presidential election of 31 October 2020. In recent times, Ghanaians have also protested as a result of widespread socio-economic challenges, such as rising inflation, high cost of living, corruption and removal of fuel subsidies on goods and services.

Nigeria has a rich history of protests, especially student protests, which played a seminal role in the struggle for the nation's independence in 1960. Thus, there has been a preponderance of protests in Nigeria. This unwelcome development is so pervasive that many have considered protests to be an indispensable part of contemporary Nigerian society. Nigerians have protested for several reasons, which include police brutality. Given that the political and socio-economic structure of Nigeria plays a key role in the determination of the roles and priority of the citizenry and the police force, various tasks of the police in Nigeria are related to the various conflicting interests among various citizens, which could threaten the peace and stability of the society. Therefore, in an attempt to ensure law and order, some police officers have resorted to the use of excessive violence and other forms of police brutality, leading to a gross violation of the human rights of Nigerians (Alemika, 1999; Ibrahim, 2016). The resulting protests against acts of brutality, especially those committed by the Special Anti-Robbery Squad (SARS), an elite group within the police force tasked with combating armed robbery and its associated crimes, have been a recurring theme in Nigerian society. The EndSARS (Special Anti-Robbery Squad) protest, which resembles related global protests, was largely unanticipated, leaderless, local and global, online and offline, violent and non-violent. As Nigerians and the global community takes stock of the immediate and future implications of the EndSARS protests, this study expands the frontiers of knowledge with a focus on the causes, consequences, and control of the EndSARS protest in Nigeria from the perspective of university students, who form a large number of the EndSARS protesters, in order to facilitate the effective management and control of future protests. 


\section{Theoretical framework}

\subsection{Concept of student protest}

While there is a consensus among various scholars that protest, whether violent or non-violent, is a social action, there is no universally accepted definition of protest. Hence, the exact meaning of protest is highly contested and debated among scholars in the extant literature. Protest has been defined as participation in several collective socio-political and problem-oriented behaviours, which vary from passive, non-violent and institutionalized acts to active, violent and unacceptable behaviours (Adejuwon \& Okewale, 2009; Singh, 2013). Adejuwon and Okewale (2009) referred to protest as the end product of human interaction, especially where there is a need to meet incompatible ends and satisfy the needs of members of the society. Imobighe (1997) referred to protest as a clash of interests between two or more parties involved in an interactive process, which leads to a state of disharmony or hostility. Wilmot and Hocket (1998) averred that protest is an expression of the struggle between two or more related parties who have to deal with incompatible goals, scarce resources and interpersonal interference in the process of achieving set goals. Bloisi (2007) defined protest as a condition of disagreement between two or more parties who have dissimilar needs and interests. Thus, individuals and groups of people are said to be engaging in protest whenever the action of one party is perceived to hamper the achievement of the goals and aspirations of another. Thus, student protest is a broad term which refers to a disagreement between students and other significant parties in the university system, such as lecturers, non-academic staff, administrators, policy makers, politicians and the host community, among others, over the distribution of resources and other issues touching on student welfare. Adeyemi, Ekundayo and Alonge (2010) posited that student protest is a situation of tension among students who are motivated to revolt against real and imagined social ills and irregularities in the school system and society at large.

\subsection{Causes of student protests}

The causes of student protests are manifold. Thus, several studies have attributed the prevalence of student protest to a broad range of internal and external factors. In other words, university students might participate in protests due to various issues, which could be primarily related to the university system or based on trending and pressing issues in the society and global community (Odebode, 2019). For instance, the Finnish Ministry of Education increased the autonomy of universities in Finland in 2010 ("Ministry of Education," 2009). By doing so, Finnish universities were allowed to be more innovative and entrepreneurial by charging tuition fees. Consequently, several university students protested in Finland to challenge the promulgation of the new legislation on student tuition fees (Hölttä, Janssen, \& Kivisto, 2010). Likewise, students at the University of Rijeka, Croatia, protested for about 20 days to express their views on the implementation of the Bologna Process, high tuition fees and the neoliberal agenda for education in 2009 (Dolenec \& Doolan, 2013).

K'okul (2010) also found that student riots in Kenyan universities were caused by age, socio-economic background, past rioting experience, financial issues, academic stress, drug abuse, lack of understanding between the students and university administrators, police brutality and political influence. Nigerian society is replete with internal factors or university-system-based causes of student protest. For instance, Davies, Ekwere and Uyanga (2013) found that the breaking of rules and regulations, lack of social amenities, student involvement in cultism, an effective student union and periodic strikes by staff of the institution were the causes of student protests at the University of Uyo, Akwa Ibom State, Nigeria. Odu (2013) reported that student protests are caused by cultism, a communication gap between authorities and the student union, youthful exuberance and the students' home background in Ebonyi and Enugu States, Nigeria. Etaneki and Okolie (2020) also found that an increase in tuition fees, dissatisfaction over academic programmes, poor leadership and cult activities were the causes of student unrest in tertiary institutions in Delta State, Nigeria. At the University of Lagos, Nigeria, students have protested, shut down the university and clashed with the 
police due to a lack of basic amenities (Abah \& Folarin, 2016). Adegun and Ojo (2016) investigated the socio-cultural factors influencing the attitude of students towards unrest in tertiary institutions in Ekiti State and revealed that exorbitant transport fares, poor management policies, an increase in school fees and a lack of social amenities were the causes of student unrest.

Further to the above, students may also play active or passive roles in protests due to various reasons or factors outside the university system. Indeed, students form a major part of the university system, which in turn forms a germane part of any modern society. Thus, external factors or matters of national and international significance could be potential drivers of student protest. For instance, students protested in Burundi over the president's bid for a third term until the government closed all universities in April, 2015 (Moore, 2015). University students in Egypt and Morocco also participated massively in the Arab Spring uprisings of 2011 to express their dissatisfaction with authoritarian regimes and unfavourable socio-economic policies (Kohstall, 2015). The separation of South Sudan from Sudan was partly due to widespread student protests across the country and unwelcome economic regulations (Hale \& Kadoda, 2014). Nigerian students have protested against various issues and changes in the socio-political landscape of Nigeria, such as the annulment of the 12 June 1993 presidential election, the Structural Adjustment Programme, an increase in fuel prices and the removal of subsidies from petroleum and related products (Davies et al., 2013; David, 2013).

\subsection{Consequences of student protests}

Student protests have several consequences for various stakeholders in society. Thus, student protests disrupt institutional activities and have contributed to poor educational standards. There is the incessant closure of institutions of learning whenever there is a protest, which adversely affects the scope and curriculum of the programmes offered (Davies et al., 2013). Chiluba (2019) found that the effects of student protests at the University of Zambia include violence and destruction of property, disruption of academic activities, suspension and punishment of students and their leaders, and the conducting of examinations without completion of the course contents. Likewise, violent student protests at the University of Zambia also precipitated the burning of tires, barricading of roads and stoning of vehicles. Consequently, many students were injured while others were arrested by the security forces (Mfula, 2016). Adeyemi (2009) concluded that the consequences of student crises in Nigerian public universities include disruption of academic programmes, destruction of lives, wanton destruction of property, closure of institutions, suspension of errant students and dismissal of students. MacGregor (2011) also noted that student protests forced the government of Togo to close the University of Lomé after two days of incessant student protests, which led to a clash with the security forces, thereby causing colossal destruction of university property and injuries among students. Hall (2016) reported that students at the University of Cape Town looted residences, disrupted the peace of the campus community and destroyed vehicles and university infrastructure, leading to the arrest and suspension of students. Odebode (2019) also noted that student protests have resulted in serious injury, death, destruction of property and disruption of peaceful co-existence within society. Vincent, Okon and Njoku (2018) also noted that destruction of lives and property worth millions of Naira and disruption of the academic calendar were the consequences of student unrest at the University of Portharcourt, Nigeria.

\subsection{Measures for controlling student protests}

The extant literature indicates that control measures for the effective control of student protests include the use of dialogue, training of school administrators in crisis management, the presence of adequate infrastructure on campuses, and the establishment of committees made up of experts in conflict management and resolution to immediately mediate in students protests, as well as the introduction of peace education into the school curriculum to make students appreciate the need for resolving differences without adopting violent means (Davies et al., 2013). Adeyemi (2009) found that a strategy of dialogue, signing of agreements with students and their parents on the prohibition of student unionism, and co-operation with students in decision-making were effective control measures 
for reducing the prevalence of student unrest at Nigerian public universities. Etaneki and Okolie (2020) concluded that student unrest could be controlled by adopting the use of effective communication, stable and moderate tuition fees, student involvement in decision-making, and effective leadership behaviour. Akeusola, Viatonu and Asikhia (2012) found that the provision of better welfare for students as well as stable and moderate tuition fees were perceived as good control measures for student crises in higher education institutions in Lagos State, Nigeria.

Likewise, Odebode (2019) proposed the use of counselling to control student protests, especially with regard to facilitating a cordial and mutual relationship between students and administrators. Ramsbothan, Miall and Woodhouse (2011) have also advocated the use of negotiation, bargaining, reconciliation, mediation, arbitration and intervention approaches in the control and management of student unrest. Likewise, Usman (2013) also noted that therapeutic counselling strategies such as dialogue, boxing the problem, arbitration, confrontation and neglect or silence could be used to control student unrest. However, neglect or silence control measures should be applied with caution, as it could turn peaceful protests into violent protests. K'okul (2010) also suggested the use of guidance and counselling for minimizing student riots in Kenyan universities. Vincent et al. (2018) suggested the use of corporate communication strategies and conflict resolution in the management of future protests at the university of Portharcourt. Kuji (2016) also found that lecturers and students in NorthWest Nigerian universities perceived citizenship and value education to be effective for the control of student unrest. While it can be concluded from the foregoing that various measures could be adopted for the effective management of student protests, it should be noted that some non-constructive measures have also been adopted by the relevant authorities to control student protests. For instance, the indiscriminate use of security forces and political thugs to control student protests has been widely condemned by experts in the field of conflict management, as it often adds more tension to already volatile conditions (Mangcu, 2016; Swart, 2016).

\subsection{Influence of gender on the perceived causes, consequences and control of student protests}

Gender refers to the status, roles, responsibilities, duties, advantages, disadvantages and power being accorded to men and women in the society. By and large, the topic of the influence of gender on individual and group behaviour, especially student protests, has been saturated by a plethora of studies in the extant literature. For instance, Odebode (2019) found that gender did not influence students' perceptions of the factors responsible for student unrest in Nigerian tertiary institutions. Similarly, Singh (2013) found that there was no significant difference in the level of student unrest among graduate students in professional and non-professional degree colleges in the city of Ghaziabad, India. However, Adegun and Ojo (2016) found no significant difference in the attitude of male and female students in tertiary institutions in Ekiti State, Nigeria towards unrest. Etaneki and Okolie (2020) found that there was no significant difference in the perception of male and female students of the causes of unrest in tertiary educational institutions in Delta State, Nigeria.

\section{Methodology}

The study was conducted to investigate the causes, consequences and control of student protests. Specifically, the study sought to investigate students' opinions on the causes, consequences and control of the EndSARS protest in Nigeria. Therefore, a quantitative type of research using the descriptive survey method of research design, which makes it possible for a researcher to explain a phenomenon or make a generalization of the entire population from a sample, was deemed appropriate. 


\subsection{Participants}

The population for this study consisted of all university students in Kwara State, Nigeria. However, the target population comprised university students in federal and state universities in Kwara State, Nigeria. Given that most of the respondents could not be accessed on the university premises due to the ASUU strike, the researcher had to intentionally choose students who reside in the university community or off-campus hostels. From selected hostels, 600 students were chosen using the convenience sampling procedure.

\subsection{Research instrument}

The Causes, Consequences and Control of Youth Protests Questionnaire (CCCYPQ) was designed and used for data collection (see Supplementary Table 1). CCCYPQ comprised Sections A-D and contained 30 items that sought information on the causes, consequences and control of the EndSARS protests. Specifically, Section A elicited respondents' bio-data; Section B elicited information on the causes of the EndSARS protests; Section C elicited information on the consequences of the EndSARS protests; and Section D elicited information on the control measures for the EndSARS protests. Sample items on the CCCYQ include: In my opinion, the EndSARS protests are caused by the loss of jobs and livelihoods during the COVID-19 lockdowns; In my opinion, the consequences of the EndSARS protests include destruction of lives and property; In my opinion, the control measures for the EndSARS protests include the provision of compensation for victims of police brutality.

The face and content validity of the CCCYPQ was established by experts in the field of education. The reliability of the questionnaire was affirmed by pre-testing it on 20 students at a private university in Ilorin, Kwara State, at an interval of two weeks. These students only participated in the pilot study because they share common characteristics with the actual respondents of this study. The two sets of scores were correlated and a reliability co-efficient of 0.78 was obtained, which was found to be reliable.

The cut-off mean score for including an item was 2.5. By implication, any item with a mean score of 2.5 or above was considered to be a cause, consequence or control measure for the EndSARS protest in Nigeria. The data and hypotheses were analysed and tested using frequency counts and percentages, means, and a t-test with significance level .05 .

\subsection{Research questions and hypotheses}

The main purpose of this study is to investigate students' opinions on the causes, consequences and control of student protests. Specifically, the study sought to answer the following research questions: "What are the causes of the EndSARS protest in Nigeria?" (RQ1); "What are the consequences of the EndSARS protest in Nigeria?" (RQ2); and "What are the control measures for the EndSARS protest in Nigeria?" (RQ3).

Based on the stated research questions, the hypotheses tested in the study are as follows: There is a significant difference in the causes of the EndSARS protest in Nigeria based on gender $(\mathrm{H} 1)$; There is a significant difference in the consequences of the EndSARS protest in Nigeria based on gender ( $\mathrm{H} 2)$; There is a significant difference in the control measures for the EndSARS protest in Nigeria based on gender $(\mathrm{H} 3)$.

\section{Results}

Supplementary Table 2 indicates the respondents' gender, age, academic level and school ownership type. Thus, out of the 600 respondents that were sampled, $343(57.17 \%)$ were males while 257 $(42.83 \%)$ were females. This indicates that the study fairly represented male university students and their female counterparts in Kwara State. However, male university students participated more in the study. Results also show that those within the range of 15-20 years old constituted the greatest 
proportion (63.0\%) of respondents; 195 (32.50\%) of the respondents were 21-30 years old, and 27 $(4.50 \%)$ of the respondents were 31 years old and above. This indicates that most of the respondents were young people or adolescents aged between 15-20 years old.

185 (57.17\%) of the respondents were 100-level students; 138 (23.0\%) of the respondents were 200level students; 107 (17.83\%) of the respondents were 300-level students; 112 (18.67) of the respondents were 400 -level students, while $58(9.67 \%)$ of the respondents were 500 -level students. Regarding the ownership of the universities attended by the protesters, $418(69.66 \%)$ of the respondents attended a federal government university, while $182(30.33 \%)$ attended a state government university.

\subsection{What are the causes of the EndSARS protest in Nigeria?}

Table 1 shows an analysis of the causes of the EndSARS protest in Nigeria by rank. It was observed that extra-judicial killings was ranked $1^{\text {st }}$, with a mean of 3.59 , while the ASSU strike action was ranked $10^{\text {th }}$, with a corresponding mean of 2.57. On the whole, it can be deduced from Table 2 that the mean scores of all the items in the table are statistically higher than 2.50 - the cut-off mean for the four-point Likert scale used for the study. This mean (2.57) indicates that all the items had an influence on the EndSARS protest in Nigeria.

Table 1

Mean and rank order of the causes of the EndSARS protest in Nigeria

\begin{tabular}{clcc}
\hline No. & Item & Mean & Rank \\
\hline 3 & Extra-judicial killings & 3.59 & $1^{\text {st }}$ \\
6 & Assaults & 3.76 & $2^{\text {nd }}$ \\
9 & Harassment & 3.41 & $3^{\text {rd }}$ \\
8 & Extortion & 3.37 & $4^{\text {th }}$ \\
5 & Bad governance & 3.03 & $5^{\text {th }}$ \\
7 & Youth unemployment & 2.95 & $6^{\text {th }}$ \\
2 & Loss of jobs and livelihoods during the COVID-19 lockdowns & 2.82 & $7^{\text {th }}$ \\
4 & Cybercrime & 2.78 & $8^{\text {th }}$ \\
10 & Social media & 2.64 & $9^{\text {th }}$ \\
1 & Strike action of the Academic Staff Union of Universities (ASUU) & 2.57 & $1^{\text {th }}$ \\
\hline
\end{tabular}

\subsection{What are the consequences of the EndSARS protest in Nigeria?}

Table 2 shows an analysis of the consequences of the EndSARS protest in Nigeria by rank. Thus, the destruction of lives and property was ranked $1^{\text {st }}$, with a mean of 3.83 , while the freezing of the bank accounts of the protesters was ranked $10^{\text {th }}$, with a corresponding mean of 2.58 . This implies that all the items represent the consequences of the EndSARS protest in Nigeria, since the means of all the items were higher than the cut-off mean of 2.50 .

Table 2

Mean and rank order of the consequences of the EndSARS protest in Nigeria

\begin{tabular}{clcc}
\hline No. & Item & Mean & Rank \\
\hline 6 & Extra-judicial killings of protesters & 3.83 & $1^{\text {st }}$ \\
4 & Destruction of lives and property & 3.78 & $2^{\text {nd }}$ \\
1 & Hacking of the websites of public ministries, departments, agencies and & 3.72 & $3^{\text {rd }}$ \\
& corporate organizations & & \\
8 & Destruction of public infrastructure facilities & 3.60 & $4^{\text {th }}$ \\
5 & Disruption of academic activities in schools & 3.09 & $5^{\text {th }}$ \\
7 & Disruption of economic activities & 2.98 & $6^{\text {th }}$ \\
9 & Imposition of curfews & 2.73 & $7^{\text {th }}$ \\
\hline
\end{tabular}




\begin{tabular}{clcc}
\hline 3 & Arrest and detention of protesters & 2.70 & $8^{\text {th }}$ \\
2 & Looting of COVID-19 relief palliatives from warehouses and stores & 2.67 & $9^{\text {th }}$ \\
10 & Freezing of the bank accounts of protesters & 2.58 & $10^{\text {th }}$ \\
\hline
\end{tabular}

\subsection{What are the control measures for the EndSARS protest in Nigeria?}

Table 3 shows an analysis of the control measures for the EndSARS protest in Nigeria by rank. Thus, the disbandment of SARS was ranked $1^{\text {st }}$, with a mean of 3.79 , while calling off the ASUU strike was ranked $10^{\text {th }}$, with a mean score of 2.53 . This shows that all the items indicate possible control measures for the EndSARS protest in Nigeria.

Table 3

Mean and rank order of control measures for the EndSARS protest in Nigeria

\begin{tabular}{clcc}
\hline No. & Item & Mean & Rank \\
\hline 3 & Disbandment of SARS & 3.79 & $1^{\text {st }}$ \\
6 & Provision of compensation for victims of police brutality & 3.74 & $2^{\text {td }}$ \\
7 & Provision of skills acquisition programmes and employment opportunities & 3.41 & $3^{\text {rd }}$ \\
& for youths & & \\
8 & Improved youth participation in governance & 3.37 & $4^{\text {th }}$ \\
5 & Provision of good governance for youths & 3.13 & $5^{\text {th }}$ \\
1 & Improved training, funding and professionalism of police officers & 2.80 & $6^{\text {th }}$ \\
4 & Dialogue & 2.73 & $7^{\text {th }}$ \\
9 & Establishing panels of inquiry concerning public complaints relating to & 2.69 & $8^{\text {th }}$ \\
& SARS & & \\
10 & Collaborative decision making & 2.57 & $9^{\text {th }}$ \\
2 & Calling off the ASUU strike & 2.53 & $1^{\text {th }}$ \\
\hline
\end{tabular}

\subsection{Testing hypotheses}

\section{There is a significant difference in the causes of the EndSARS protest in Nigeria based on gender}

Regarding the causes of the EndSARS protest in Nigeria, the mean score for male respondents was $M$ $=17.26(S D=8.27)$ and for female respondents was $M=15.19(S D=6.93)$, which was in favour of the male students. However, this difference did not reach significance $(p=.35)$ with regard to gender.

There is no significant difference in the consequences of the EndSARS protest in Nigeria based on gender

The mean score for male respondents was $M=13.57$ (SD = 7.81) and for female respondents was $M=$ $12.74(S D=6.30)$ regarding the consequences of the EndSARS protest in Nigeria; this also favoured male students. However, there was no significant difference in the consequences of the EndSARS protest in Nigeria based on gender $(p=.19)$.

There is no significant difference in the control measures for the EndSARS protest in Nigeria based on gender

The difference between the mean scores for male respondents $(M=16.34, S D=7.45)$ and female respondents ( $M=15.19, S D=5.92)$ regarding the control measures for the EndSARS protest in Nigeria was in favour of the male students. However, there was no significant difference in the control measures for the EndSARS protest in Nigeria based on gender $(p=.57)$. 


\section{Discussion}

Millions of Nigerian youths protested for the disbandment of the SARS unit in October 2020. Thus, the present study was carried out to investigate students' opinions on the causes, consequences and control measures for the EndSARS protest in Nigeria. It was found that the EndSARS protest in Nigeria was caused by extra-judicial killings, assaults, harassment, extortion, bad governance, youth unemployment, loss of jobs and livelihoods during the COVID-19 lockdowns, cybercrime, social media and the strike action of the ASUU. This is in agreement with the submissions of previous researchers, such as Adeyemi (2009), Odu (2013) and Obi (2014). This could be a result of the nature of the respondents, who are literate, knowledgeable and mature enough to observe or experience the causes of various phenomena in the society, such as widespread police brutality and its associated extrajudicial killings, assaults, extortion, harassment, and a host of others. Taken together, police brutality and its associated socio-economic issues form a good breeding ground for protests in Nigeria (Adegun \& Ojo, 2016; Alemika, 1999; Davies et al., 2013; Ibrahim, 2016).

Nigerian university students are digital natives or migrants who use various technological devices and applications to perform various tasks on a daily basis. Given the worrisome rate of unemployment among Nigerian youths, it is not surprising that some university students seek out alternative sources of income, thereby indulging in cybercrime (Asaju, Arome, \& Anyio, 2014). Thus, as these students get more money from various acts of cybercrime, they tend to live a lavish lifestyle, which might include wearing dreadlocks/coloured hair and tattoos, dressing in crazy clothes, driving exotic cars, using costly smartphones, laptops and other ICT devices, and spending huge sums of money at clubs and parties. By doing so, the SARS officials who patrol the hidden depths of Nigerian society might deem such students suspicious, or intentionally track the movements of identified online fraudsters who reside in various student hostels in the university community.

University students in Nigeria are frequent users of social media for various purposes (Onivehu, Adegunju, Ohawuiro, \& Oyeniran, 2018). It therefore follows that social media platforms such as YouTube, Facebook, WhatsApp, Instagram and Twitter contributed greatly to the circulation of photos, videos, comments, ideas, trending news and fake news during the EndSARS protest by providing audiovisual spectacles, which stimulate emotional feelings towards the protest (Jenkins, 2019; McGarry, Jenzen, Eslen-Ziya, Erhart, \& Korkut, 2019).

As action begets reaction, the EndSARS protest was associated with some consequences in Nigerian society. Thus, the study indicated that the EndSARS protest was associated with the extra-judicial killings of protesters, destruction of lives and property, hacking of the websites of public ministries, departments, agencies and corporate organizations, destruction of public infrastructure facilities, disruption of academic activities in schools, imposition of curfews, arrest and detention of protesters, and looting of COVID-19 palliatives from warehouses and stores. This finding is in consonance with the findings of some studies on the consequences of student protests in Nigeria (Adeyemi, 2009; Davies et al., 2013; Odebode, 2019; Vincent et al., 2018). Nigerian youths embarked on widespread destruction of lives and property, hacking of the websites of public ministries, departments, agencies and corporate organizations, destruction of public infrastructure facilities, and looting of COVID-19 palliatives from warehouses and stores to get even with the relevant authorities during the EndSARS protest. As a preventive measure, security agents arrested and detained some protesters, while some state governments imposed various curfew periods to keep the society safe. Likewise, teachinglearning activities were on hold in the schools, especially in the primary and secondary schools as well as higher institutions of learning.

The respondents also indicated that the measures for controlling the EndSARS protest include the disbandment of SARS, provision of compensation for victims of police brutality, provision of skills acquisition programmes and employment opportunities for youths, improved youth participation in governance, provision of good governance for youths, improved training and funding of the police force, dialogue, establishment of panels of inquiry on public complaints relating to SARS, collaborative 
decision making, and cancellation of the strike of the ASUU. The SARS unit of the Nigerian Police Force had been disbanded by the Inspector General of Police. In this regard, the leadership of the Nigerian Police Force deserves some commendation for professionally handling the EndSARS protest, despite pockets or reported cases of police brutality during the protests. The Nigerian government also constituted various panels of inquiry to investigate cases of police brutality in Nigeria. It is therefore necessary that the panels carry out their mandates with maximum professionalism. Consequently, identified victims of police brutality should be properly compensated by the government. There is also the need for the government to provide adequate counselling and psychosocial support for victims of police brutality in Nigeria, especially those who are grappling with various degrees of depression, suicidal ideation, substance abuse, Post Traumatic Stress Disorder (PTSD), insomnia and other mental health issues at Nigerian universities (Odebode, 2019).

The Nigerian government should provide more opportunities for university students and other Nigerian youths to be gainfully employed in the formal and informal sectors. Moreover, youths should be engaged in constant dialogue with elders and the political class in Nigerian society. This will facilitate trust, understanding, co-operation, collaborative decision-making and peaceful co-existence among Nigerians (Etaneki \& Okolie, 2020; Usman, 2013). The ASUU strike also contributed in one way or the other to the EndSARS protest. In this regard, the Nigerian government and the ASUU also deserve some commendation for calling off the strike in December 2020. It is therefore hoped that, as Nigerian universities commence teaching-learning activities in the post-EndSARS protest era, university students and other youths will be able to live peacefully without being worried about the menace of police brutality.

The $t$-test computation on the difference in the causes, consequences and control measures for the EndSARS protest in Nigeria based on gender indicated that there is no significant difference in the causes, consequences and control measures for the EndSARS protest based on gender. This finding is better understood in light of the fact that male university students and their female counterparts reside in the environment and have therefore experienced the dynamic of the EndSARS protest. In a like manner, this finding could be attributed to the various sources of information available to male university students and their female counterparts on the causes, consequences and possible measures for controlling the EndSARS protest in Nigeria (Adegun \& Ojo, 2016; Etaneki \& Okolie, 2020; Odebode, 2019).

\section{Conclusion}

Based on the findings of the study, one could conclude that the EndSARS protest in Nigeria was caused by extra-judicial killings, assaults, harassment, extortion, bad governance, youth unemployment, loss of jobs and livelihoods during the COVID-10 lockdowns, cybercrime, social media and the strike action of the ASUU. It is also the submission of the researcher that the consequences of the EndSARS protest include extra-judicial killings of protesters, destruction of lives and property, hacking of the websites of public ministries, departments, agencies and corporate organizations, destruction of public infrastructure facilities, disruption of academic activities in schools, imposition of curfews, arrest and detention of protesters, and looting of COVID-19 palliatives from warehouses and stores. The results of the study also indicate that the control measures for the EndSARS protest include the disbandment of SARS, provision of compensation for victims of police brutality, provision of skills acquisition programmes and

The EndSARS protest was caused by various acts of police brutality, while the consequences of the protest include destruction of lives and property. The disbandment of SARS and provision of compensation for victims of police brutality were found to be control measures for the protest. 
employment opportunities for youths, improved youth participation in governance, provision of good governance for youths, improved training, funding and professionalism of police officers, dialogue, establishment of panels of inquiry on public complaints relating to SARS, collaborative decisionmaking, and cancellation of the strike of the ASUU.

\subsection{Recommendations}

The major findings indicate that the EndSARS protest was caused by various acts of police brutality, while the consequences of the protest include the extra-judicial killing of protesters. The findings also reveal the disbandment of SARS as a control measure for the EndSARS protest. With these findings: (i) The Nigerian government and the relevant authorities should work with identified leaders of student protests in the future to ensure that dialogue and collaborative decision-making is given more priority over the use of excessive force to stop students from engaging in protests; (ii) Social educators, through the Social Studies Association of Nigeria (SOSAN), should periodically organize seminars, conferences and workshops to equip parents, university students, community members, school administrators and lecturers with the required life skills in order to produce violence-free students at universities. Such seminars, conferences or workshops should be geared towards building the skills of tolerance and conflict resolution in staff, students and other stakeholders in the university system to ensure peaceful co-existence in the society; and (iii) The Nigerian Police Force should be friendlier and more tolerant in dealing with various youths in Nigerian society, especially university students who have various maladaptive behaviours.

\section{Declaration of conflicting interests}

No potential conflict of interest is reported by the author.

\section{Acknowledgements}

I wish to extent my profound gratitude to the university students who participated in the study. This work would have been impossible without the help of the editorial team and anonymous reviewers, who were always available to offer valuable insights and provide clarifications.

\section{References}

Abah, C., \& Folarin, S. (2016, April 8). UNILAG shut down over students protest. News @ Punch. Retrieved from https://punchng.com/unilag-students-shut-down-school-over-power-outage

Adegun, O. A., \& Ojo, G. A. (2016). Socio-cultural determinants of students' attitude towards unrest in tertiary institutions in Ekiti State. Social Science Education Journal, 1(1), 161-167. Retrieved from http://soscedj.eksu.edu.ng/wp-content/uploads/2019/04/No-31-Adegun-and-Ojo.pdf

Adejuwon, K., \& Okewale, R. (2009). Ethnic militancy, insurrections and democracy in Africa: The case of Nigeria. Journal of Social and Policy Issues, 6(4), 79-90.

Adeyemi, T. O. (2009). Causes, consequences and control of student's crises in public and private universities in Nigeria. Academic Journals of Educational Research and Review, 4(4), 156-163.

Adeyemi, T. O., Ekundayo, H. T., \& Alonge, H. O. (2010). Managing students' crisis in tertiary institutions in Nigeria. Journal of Research in National Development, 8, 1-15.

Akeusola, O., Viatonu, O., \& Asikhia, O. A. (2012). Perceived causes and control of student's crises in higher institutions in Lagos State, Nigeria. Journal of Education and Practice, 3(10), 29-43. Retrieved from https://core.ac.uk/download/pdf/234633583.pdf

Alemika, E. E. O. (1999). 'Police-community relations in Nigeria: What went wrong?' Center for Law Enforcement Education and the National Human Rights Commission, Policing a Democracy: A Survey report on the roleand functions of the Nigerian police in a post-military era. Lagos: CLEEN/NHRC. 
Asaju, K., Arome, S., \& Anyio, S. (2014). The rising rate of unemployment in Nigeria: The Socioeconomic and political implications. Global Business and Economic Research Journal, 3(2), 12 32.

Bloisi, W. (2007). An introduction to human resources management. London: McGraw-Hill.

David, A. (2013). Students' crisis in Nigerian tertiary educational institutions: A review of the causes and management style. Khazar Journal of Humanities and Social Sciences, 16(1), 56-75.

Davies, K. U., Ekwere, G. E., \& Uyanga, U. U. (2013). Factors influencing students unrest in institutions of higher learning and its implications on the academic performance of students in university of Uyo, Akwa Ibom State, Nigeria. Research in Pedagogy, 6(1), 27-42. https://doi.org/10.17810/2015.21

Dolenec, D., \& Doolan, K. (2013). Reclaiming the role of higher education in Croatia: Dominant and oppositional framings. In P. Zgaga, U. Teicher, \& J. Brenan (Eds.), The globalization challenge for European higher education (pp. 325-346). Frankfurt am Main: Peter Lang Edition.

Ekundayo, H. T., \& Alonge, H. O. (2010). Managing students' crisis in tertiary institutions in Nigeria. Journal of Research National Development, 8(1), 71-90.

Etaneki, A. F., \& Okolie, U. C. (2020). Students' unrest: An evaluation of influencing factors and control in tertiary educational institutions in Delta State, Nigeria. Journal Plus Education, 25(1), 192210. Retrieved from https://uav.ro/jour/index.php/jpe/article/view/1456/1507

Hale, S., \& Kadoda, G. (2014). The changing nature of political activism in Sudan: Women and youth 'activists' as catalysts in civil society. In E. Grawert (Ed.), Forging two nations: Insights on Sudan and South Sudan (pp. 65-79). Berlin: African Books Collective.

Hall, M. (2016, March 3). South Africa's student protests have lessons for all universities. Universities @ The Guardian. Retrieved from https://www.theguardian.com/higher-educationnetwork/2016/mar/03/south-africas-student-protests-have-lessons-for-all-universities

Hölttä, S., Janssen, T., \& Kivisto, J. (2010). Emerging markets in the Finnish system. In R. Brown (Ed.), Higher education and the market (pp. 123-134). Oxford: Routledge.

Chiluba, B. C. (2019). Strategies for social engagement: The University of Zambia student unrests. International Journal of Research and Innovation in Social Science, 3(7), 267-271.

Ibrahim, A. (2016). Police corruption and the state: Prevalence and consequences. Global Journal of Arts Humanities and Social Sciences, 4(9), 32-42.

Imobighe, T. A. (1997). Conflict management in Nigeria. In I. B. Bello-Imam (Ed.), Government in Nigeria: Economy, politics and society in the adjustment years, 1985-1995 (pp. 273-287). Ibadan: Stirling Harden Ltd.

Jenkins, M. D. (2019). Explaining cross-country variation in collective action in the digital era. Journal $\begin{array}{lllll}\text { of Information } \quad \text { Technology 1-19. } & \text { Politics, }\end{array}$ https://doi.org/10.1080/19331681.2019.1572567

K'okul, F. S. (2010). Perceptions of students on the status of guidance and counselling in selected universities in Kenya for minimizing student riots (Unpublished doctoral dissertation thesis). School of Education, Kenyatta University, Kenya.

Kohstall, F. (2015). From reform to resistance: Universities and student mobilization in Egypt and Morocco before and after the Arab uprisings. British Journal of Middle Eastern Studies, 42(1), 59-73. https://doi.org/10.1080/13530194.2015.973183 
Kuji, J. A. (2016). Lecturers and students' perception of impact of citizenship and values education in checking university students unrest in North-West, Nigeria (Unpublished doctoral dissertation thesis). Ahmadu Bello University, Zaria, Nigeria.

MacGregor, K. (2011, June 5). TOGO: Lomé campus closed after student violence. African Edition @ University World News. Retrieved from https://www.universityworldnews.com/post.php?story=20110604092616781

Mangcu, X. (2016). Leadership key to campus racism: Universities need to listen more closely to students and devise a new governance model. News @ Sunday Independent. Retrieved from https://www.iol.co.za/sundayindependent

McGarry, A., Jenzen, O., Eslen-Ziya, H., Erhart, I., \& Korkut, U. (2019). Beyond the iconic protest images: The performance of everyday life on social media during Gezi Park. Social Movement Studies, 18(1), 1-21. https://doi.org/10.1080/14742837.2018.1561259

Mfula, C. (2016, February 4). Zambia closes two government universities after student protests. Top News@ Reuters. Retrieved from https://www.reuters.com/article/ozatp-us-zambia-protestidAFKCNOVDOUZ

Ministry of Education, Finland. (2009). Strategy for the internationalization of higher education institutions in Finland 2009-2015. Retrieved from https://julkaisut.valtioneuvosto.fi/bitstream/handle/10024/77779/opm23.pdf?sequence=1

Moore, P. (2015, June 25). Burundi student protesters seek refuge in US embassy. News @ Al Jazeera. Retrieved from https://www.aljazeera.com/news/2015/6/25/burundi-student-protesters-seekrefuge-in-us-embassy

Obi, C. N. (2014). Improved tertiary institution students crisis management with basic principles of administration. Journal of Resourcefulness and Distinction, 9(1), 1-9. Retrieved from https://www.globalacademicgroup.com/journals/resourcefulness/Improved\%20Tertiary\%20In stitution\%20Students\%20Crisis\%20Management.pdf

Odebode, A. A. (2019). Factors responsible for students' unrest in Nigerian tertiary institutions: Implications for counselling practices. Mimbar Pendidikan: Jurnal Indonesia untuk Kajian Pendidikan, 4(2), 93-102.

Odu, O. M. (2013). Management of student crisis in higher institutions of learning in Nigeria. Mediterranean Journal of Social Sciences, 4(8), 1-8. https://doi.org/10.5901/mjss.2013.v4n8p91

Onivehu, A. O., Adegunju, A. K., Ohawuiro, E. O., \& Oyeniran, J. B. (2018). The relationship among ICT utilization, SRL and academic performance of prospective teachers. Acta Didactica Napocensia, 11(1), 69-85. https://doi.org/10.24193/adn.11.1.6

Ramsbothan, O., Miall, H., \& Woodhouse, T. (2011). Contemporary conflict resolution. Malden, MA: Polity Press.

Singh, B. (2013). A study of student unrest among graduate students in relation to their gender, intelligence, adjustment and educational stream. International Journal of Education and Psychological Research, 2(1), 40-46.

Swart, M. (2016, January 29). Students are not the enemy: The securitization of campuses flies in the face of open debate and the freedom of expression. News @ Mail - Guardian, Education. Retrieved from https://www.sun.ac.za/english/Documents/In\%20the\%20news/29\%20Jan\%20\%20Mail\%20and\%20Guardian\%20(Students\%20are\%20not\%20the\%20enemy).pdf

Usman, I. G. (2013). Students' unrest and use of therapeutic counselling strategies for resolving students' crisis in Nigerian universities. American Based Research Journal, 2(5), 52-56. Retrieved from https://zenodo.org/record/3408174\#.YGEcZjwzXIU 
Vincent, R., Okon, G. B., \& Njoku, N. U. (2018). Corporate communication strategies and conflict resolution in tertiary institutions: A focus on UNIPORT 2016 unrest. International of Innovative Development and Policy Studies, 6(4), 10-20. Retrieved from https://seahipaj.org/journalsci/dec-2018/IJIDPS/full/IJIDPS-D-2-2018.pdf

Wilmot, W. W., \& Hocker, J. L. (1998). Interpersonal conflict. Boston: McGraw-Hill Education.

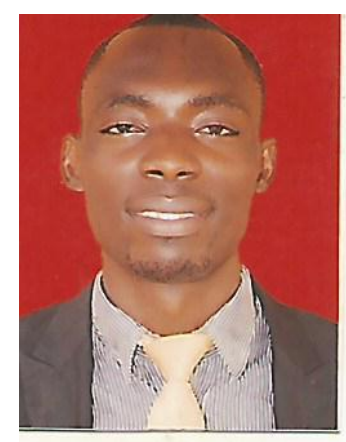

Adams Ogirima Onivehu is a postgraduate researcher in the Department of Social Sciences Education, University of Ilorin, Ilorin, Nigeria, where he specializes in the field of Educational Psychology. His diverse background and field experience in the fields of Educational Technology and Psychology, along with a gnawing curiosity, have resulted in a series of interdisciplinary research interests, which is reflected in several articles published by national and international outlets. He has attended many national and international conferences. 
Dear respondent,

The researcher is carrying out a study on the causes and consequences of student protests, especially the EndSARS protest in Nigeria. You are implored to please assist by objectively responding to the questionnaire. The information supplied will be treated with the utmost confidentiality and used for research purposes only.

Thank you for your anticipated co-operation.

SECTION A: Demographic data

Directions: Kindly tick $(\sqrt{ })$ as applicable to you.

1. Gender: Male ( ); Female ( )

2. Age: $15-20$ years ( ); 21-30 years ( ); 31 years and above ( )

3. Academic Level: 100 ( ); 200( ); 300( ); 400( );500()

4. School Ownership Type: Federal Government ( ); State Government ( ); Other

Section B: Causes of the EndSARS protest

Directions: Kindly tick $(\sqrt{ })$ as applicable to you.

Key: Strongly Agree (SA); Agree (A); Disagree (D); Strongly Disagree (SD)

SIN In my opinion, the EndSARS protest is caused by:

1 The strike action of the Academic Staff Union of Universities (ASUU)

2 Loss of jobs and livelihoods during the COVID-19 lockdowns

3 Extra-judicial killings

4 Cybercrime

5 Bad governance

6 Assaults

7 Youth unemployment

8 Extortion

9 Harassment

10 Social media

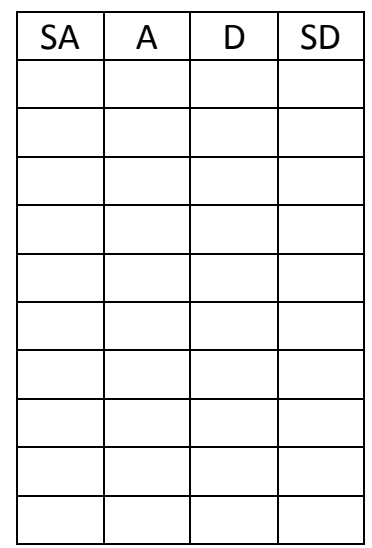

\section{Directions: Kindly tick $(\sqrt{ })$ as applicable to you.}

Key: Strongly Agree (SA); Agree (A); Disagree (D); Strongly Disagree (SD)

SIN In my opinion, the consequences of the EndSARS protest include:

1 Hacking of the websites of public ministries, departments, agencies and corporate organizations

2 Looting of COVID-19 relief palliatives from warehouses and stores

3 Arrest and detention of protesters

4 Destruction of lives and property

5 Disruption of academic activities in schools

6 Extra-judicial killings of protesters

7 Disruption of economic activities

8 Destruction of public infrastructure facilities

9 Imposition of curfews

10 Freezing of the bank accounts of protesters

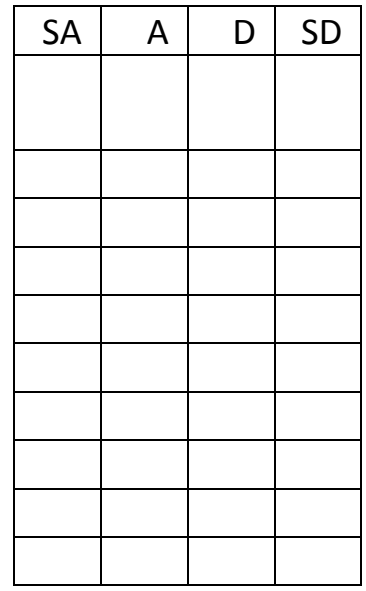


Section C: Control measures for the EndSARS protest

Directions: Kindly tick $(\sqrt{ })$ as applicable to you.

Key: Strongly Agree (SA); Agree (A); Disagree (D); Strongly Disagree (SD)

SIN In my opinion, the control measures for the EndSARS protest include:

1 Improved training, funding and professionalism of police officers

2 Calling off the Academic Staff Union of Universities (ASUU) strike

3 Disbandment of SARS

4 Dialogue

5 Provision of good governance for youths

6 Provision of compensation for victims of police brutality

7 Provision of skills acquisition programmes and employment opportunities for youths

8 Improved youth participation in governance

9 Establishment of panels of inquiry on public complaints relating to SARS

10 Collaborative decision-making

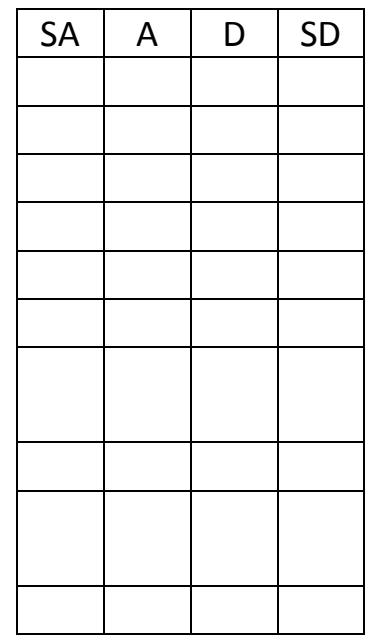


Supplementary Table 2. Demographic distribution of respondents by gender, age, academic level and school ownership $(n=600)$

\begin{tabular}{lcc}
\hline Variable & Frequency $(n)$ & Percentage (\%) \\
\hline Gender & 343 & 57.17 \\
$\quad$ Male & 257 & 42.83 \\
$\quad$ Female & & \\
Age & 378 & 63.00 \\
15-20 years & 195 & 32.50 \\
21-30 years & 27 & 4.50 \\
31 years and above & & \\
Academic level & 185 & 30.83 \\
100 & 138 & 23.00 \\
200 & 107 & 17.83 \\
300 & 112 & 18.67 \\
400 & 58 & 9.67 \\
500 & & \\
School ownership type & 418 & 69.66 \\
Federal government & 182 & 30.33 \\
State government & & \\
\hline
\end{tabular}

